\title{
Role of CD44 as a marker of cancer stem cells in head and neck cancer
}

\author{
This article was published in the following Dove Press journal: \\ Biologics:Targets and Therapy \\ 31 October 2012 \\ Number of times this article has been viewed
}

\author{
Serena Trapasso \\ Eugenia Allegra \\ Otolaryngology - Head and Neck \\ Surgery, University Magna Graecia \\ of Catanzaro, Catanzaro, Italy
}

Correspondence: Eugenia Allegra Unità Operativa di Otorinolaringoiatria, Università Magna Graecia di Catanzaro,

Viale Europa, Località Germaneto,

Catanzaro 88100, Italy

$\mathrm{Tel}+39096 \mid 3647130$

$\mathrm{Fax}+39096 \mid 364713$ |

Email eualle@unicz.it

\begin{abstract}
In recent years, many studies have shown that some types of tumors are characterized by the presence of cells with stem-like characteristics, called cancer stem cells (CSCs). These are considered cells that initiate the tumor and are probably responsible for tumor recurrence. CSCs have the capacity for self-renewal, the potential to give rise to one or more cell types within the tumor, and the ability to drive, in a continuous manner, the proliferation of malignant cells. The failure of current cancer therapies can be attributed to the relative ineffectiveness of drugs against CSCs, which remain viable while retaining their full ability to reproduce the tumor. The development of new strategies is currently hampered by the lack of reliable markers to identify CSCs. One promising surface marker of CSCs in head and neck cancer is the CD44 molecule, which has been shown in preliminary studies to have high specificity, although there are discrepant data because its prognostic value may depend on the specific tumor location. More rigorous studies are needed to investigate the usefulness of CD44 expression in head and neck tumors for possible clinical applicability.
\end{abstract}

Keywords: CD44, head and neck squamous cell carcinoma, cancer stem cells

\section{Introduction}

Emerging studies show that CD44 is an important biomarker of a cellular subpopulation cancer stem cells (CSCs) - which are capable of self-renewal and have the capacity for initiation, progression, invasion, metastasis, tumor recurrence, and resistance to chemo- and radiotherapy. ${ }^{1}$ This cell subpopulation was isolated for the first time by Bonnet and Dick from samples of acute myeloid leukemia. ${ }^{2} \mathrm{CSC}$ s have also been identified in solid tumors. Al-Hajj et al identified a subpopulation of CD $44^{+} / \mathrm{CD} 24^{-}$cells with tumorigenic capacity from breast cancer samples in 2003. ${ }^{3}$ CSCs were also identified in brain tumors by Singh et al in $2003,{ }^{4}$ in prostate tumors by Collins et al in $2005,{ }^{5}$ in colorectal cancers by Dalerba et al in $2007,{ }^{6}$ in pancreatic tumors by $\mathrm{Li}$ et al, ${ }^{7}$ and in lung tumors by Ho et al. ${ }^{8}$

In 2007, Prince et al first identified a cellular subpopulation in head and neck tumors expressing the surface marker CD44 with stem-like characteristics; these cells were capable of reproducing when implanted into immunosuppressed mice. ${ }^{9}$ In the same year, Harper et al studied the expression of CD44, CD29, and CD133 as presumed markers of CSCs in cell lines derived from head and neck tumors; they found that the greatest expression of CD44 correlated with increased clonogenicity. ${ }^{10}$

\section{CD44}

CD44 is a type I transmembrane glycoprotein expressed in several cell types of mesenchymal and neuroectodermal origin. ${ }^{11}$ CD44 functions as a major adhesion molecule 
and in the cellular internalization of hyaluronic acid. ${ }^{12}$ The interaction between hyaluronic acid and CD44 influences adhesion to components of the extracellular matrix, and it is involved in the stimulation of aggregation, cell proliferation and migration, and angiogenesis. ${ }^{13}$ All of these biological properties are essential to normal cell physiology, but in certain conditions they are associated with pathological activities, in particular those of cancer cells. ${ }^{14}$

The bond between hyaluronic acid and the CD44 adhesion molecule may initiate a series of events that begin with modification of adhesion to the matrix and continue with activation of other molecules such as growth factors, degradation of the matrix, angiogenesis, permeation by blood vessels, and extravasation. ${ }^{15}$ All of these steps are necessary in the initiation of metastasis. ${ }^{16}$ In addition to hyaluronic acid, CD44 binds to fibronectin, the invariant part of the major histocompatibility complex class II, ${ }^{17}$ and high-molecularweight proteoglycans. ${ }^{18}$ The heterogeneity of CD44 binding to these ligands reflects the fact that the gene encoding CD44 comprises 20 exons; the first and the last five are constant, and the central ten are subjected to alternative splicing, thus constituting the variable region of the receptor. ${ }^{19}$ The most common isoform of the receptor is CD44 standard, which is highly expressed in hematopoietic cells. About 30 receptor variants $(\mathrm{CD} 44 \mathrm{v})$ have been identified, many of which appear to be expressed on tumor cells and arise from alternative splicing at the extracellular proximal portion of the receptor. ${ }^{20}$ In pathological conditions such as cancer, the extracytoplasmic domain of the CD44 receptor detaches and is released into biological fluids as a soluble fraction of the receptor CD44sol. ${ }^{21-25}$

Numerous studies have highlighted the connection between CD44, hyaluronic acid, and the PI3K-Akt system, whose stimulation leads to phosphorylation of Akt (also known as protein kinase B). p-Akt is positively involved in the processes of cell survival and in the development of resistance to chemotherapy. ${ }^{26}$ Activation of this enzyme triggers a series of reactions, all of which increase cell proliferation and survival through the transformation of phosphatidylinositol-4,5-bisphosphate, located in the cytoplasmic membrane, to phosphatidylinositol-3,4,5triphosphate, which activates the effector molecule Akt. Akt is a Ser-Tyr kinase whose active form p-Akt phosphorylates a number of proteins involved in cell proliferation (Figure 1). For example, Akt is involved in the maintenance of cell metabolism in growth-limiting conditions through adenosine triphosphate production via glycolysis; increased cellular uptake of glucose by glucose transporter type 4; mammalian target of rapamycin phosphorylation, which increases the synthesis of cyclin D; intracellular activation of transcription factors such as S6 kinase and apoptosis through BAD phosphorylation/inactivation; and reduction in proapoptotic gene transcription through phosphorylation of AFX, FKHR, and FKHRL1. ${ }^{27,28}$

Alteration in the $\mathrm{T}$ lymphocyte-mediated immune response can change the expression of $\mathrm{CD} 44$ and its role in lymphocyte homing. CD44 is also involved in the transport of circulating lymphocytes to lymph nodes and in lymphocytic-epithelial interactions, through which it modulates lymphocyte adhesion and activation. ${ }^{29}$ These roles form the basis of the idea that CD44 plays an important role in lymph-node metastasis and in the potential carcinogenicity of certain forms of T-cell leukemia and lymphoma. The proposed pathway involves promoting the survival of $\mathrm{T}$ cells by increasing their resistance to apoptosis induced experimentally by corticosteroid treatment or ultraviolet rays through a p53-dependent mechanism involving the inhibition of DNA fragmentation. ${ }^{30}$

\section{Clinical studies}

Currently, researchers continue to study the biological characteristics of the surface CD44 molecule as a marker of cancer stem cells (Allegra and Trapasso, unpublished data, 2012). However, there are conflicting findings about the clinical significance of CD44 expression.

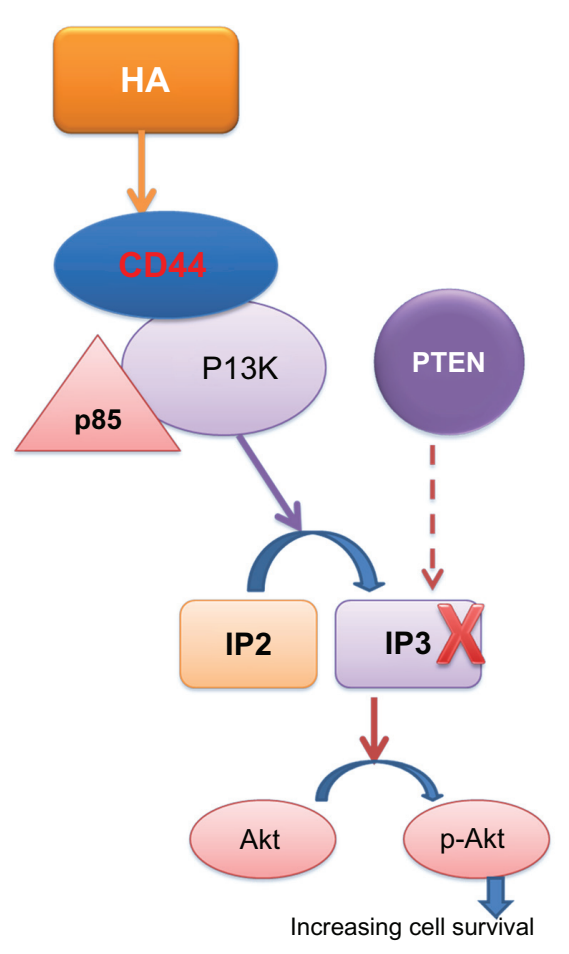

Figure I Increasing cell survival mediated by CD44. Abbreviation: HA, hyaluronic acid. 
Joshua et al have studied a lineage-CD44 ${ }^{+}($Lin-CD44 $)$ subpopulation of cells with cancer stem cell properties in head and neck squamous cell carcinoma, and they have observed a high frequency of Lin-CD44+ cells correlated with known poor prognostic factors such as advanced $\mathrm{T}$ classification and recurrence. ${ }^{31}$ In some cases, the overexpression of $\mathrm{CD} 44 \mathrm{v}$ (v3 and $\mathrm{v} 6$ ) seems to reflect the cellular invasiveness and leads to increased aggressiveness of tumors in the head/ neck, such as in carcinoma of the oral cavity. ${ }^{32}$ Understanding CD44 is important to the study of tumor progression and invasiveness because invasive tumors attack the extracellular matrix of surrounding tissues for expanding; the interaction between CD44 and hyaluronic acid plays a decisive role in various cellular pathways. ${ }^{33,34}$

There are clear discrepancies in the interpretation of the expression of CD44 in relation to tumors of various head and neck regions with different biological characteristics. In squamous cell carcinomas of the oral cavity, the evidence seems to indicate that a low expression of CD44 correlates with a greater capacity for metastasis and recurrence, with negative prognostic significance or no significant impact on prognosis..$^{35,36}$ There are few studies of oropharyngeal cancer, and the results are inconsistent. Rajarajan et $\mathrm{al}^{37}$ and Carinci et $\mathrm{al}^{38}$ found no evidence of expression of CD44 or prognostic significance, whereas Lindquist et a $\mathrm{l}^{39}$ and Kokko et $\mathrm{al}^{36}$ reported a correlation between high expression of CD44 and poor prognosis. In squamous cell carcinoma of the tongue, the few available clinical trials reported by Fonseca et al showed a relationship between lack of expression of CD44 and lateral cervical lymph-node metastases. ${ }^{40}$ This finding is similar to those of Mostaan et al, ${ }^{41}$ Rodrigo et $a 1,{ }^{42}$ and Masuda et $\mathrm{al},{ }^{43}$ who reported a correlation between the expression of CD44 and low propensity for metastasis and poor prognosis.

Instead, the high expression of CD44 in laryngeal tumors seems to correlate more strongly with a poor prognosis. This contrasts with other locations of head and neck cancer, in which high expression of CD44 correlates with a greater capacity for locoregional or distant metastasis and resistance to radiochemotherapy. ${ }^{44-46}$ It is becoming increasingly clear that differences in the ability for locoregional or distant metastasis and radioresistance seem to depend on the overexpression of specific CD44v: Sun et $\mathrm{al}^{47}$ and $\mathrm{Lu}$ et $\mathrm{al}{ }^{48}$ have shown that high expression of CD44 correlates with a greater tendency to develop metastatic lymph nodes, recurrence, and radioresistance. The different isoforms CD44v3 and CD44v6 seem to correlate with lymph-node metastasis, systemic diffusion, and failure of radiation therapy. ${ }^{49}$ The metastatic potential identified by markers of CSCs in tumors of the head and neck was recognized in a study that considered other candidate biomarkers of CSCs such as BMI1 with significant implications for clinical outcomes ${ }^{50}$ For example, in laryngeal carcinoma, high expression of BMI1 combined with the absence of p16 expression implies the presence of lymph-node metastases. ${ }^{51}$

Considering the role of CD44 in the activation of cell replication, its antiapoptotic activity, and its potential as a marker of CSCs in epithelial tumors, we decided to study the role of CD44 standard in head and neck tumors. We studied the levels of CD44 sol in the saliva of patients with tumors of the larynx,${ }^{52}$ starting from the assumption that in the normal upper aerodigestive tract, CD44 is expressed on the basal surface, whereas in the histologically dysplastic epithelium, CD44 is expressed in all layers of the mucosa in more than $90 \%$ of cases. This overexpression is also present in $90 \%$ of invasive head and neck tumors. ${ }^{52,53}$ Our results were encouraging because we found high levels of CD44sol in most patients with laryngeal carcinoma with high specificity compared with controls, and the highest levels of CD44sol were observed in patients with advanced stages of disease. Our and Franzmann et al's results are promising because of their high diagnostic power, and suggest that CD44sol could be a specific diagnostic marker of head and neck cancer. ${ }^{52,55-57}$

These data are superior to those obtained by other studies using various markers with different methods of investigation such as loss of heterozygosity, the methylation-specific markers, telomerase activity, mitochondrial DNA mutations, and recently the multiplexed immunobeaded-based technology. ${ }^{58-63}$

\section{Conclusion}

CD44 appears to be a fairly reliable marker of head and neck tumors and to have potential diagnostic value, because its detection is easy and there are clinical benefits in terms of final outcomes. Cruz et al wrote, "The identification of a fraction of cancer stem cells (CSCs) associated with resistance to chemotherapy in most solid tumors leads to the dogma that eliminating this fraction will cure cancer." ${ }^{64}$

Further studies are needed to validate this theory and to consolidate the role of CD44 as a biomarker of CSCs in head and neck cancer.

\section{Disclosure}

The authors report no conflicts of interest in this work. 


\section{References}

1. Koukourakis MI, Giatromanolaki A, Tsakmaki V, Danielidis V, Sivridis E. Cancer stem cell phenotype relates to radio-chemotherapy outcome in locally advanced squamous cell head-neck cancer. $\mathrm{Br} J$ Cancer. 2012;106:846-853.

2. Bonnet D, Dick JE. Human acute myeloid leukemia is organized as a hierarchy that originates from a primitive hematopoietic cell. Nat Med. 1997:3:730-737.

3. Al-Hajj M, Wicha MS, Benito-Hernandez A, Morrison SJ, Clarke MF. Prospective identification of tumorigenic breast cancer cells. Proc Natl Acad Sci U SA. 2003;100:3983-3988.

4. Singh SK, Clarke ID, Terasaki M, et al. Identification of a cancer stem cell in human brain tumors. Cancer Res. 2003;63:5821-5828.

5. Collins AT, Berry PA, Hyde C, Stower MJ, Maitland NJ. Prospective identification of tumorigenic prostate cancer stem cells. Cancer Res. 2005;65:10946-10951.

6. Dalerba P, Dylla SJ, Park IK, et al. Phenotypic characterization of human colorectal cancer stem cells. Proc Natl Acad Sci U S A. 2007;104:10158-10163.

7. Li C, Heidt DG, Dalerba P, et al. Identification of pancreatic cancer stem cells. Cancer Res. 2007;67:1030-1037.

8. Ho MM, Ng AV, Lam S, Hung JY. Side population in human lung cancer cell lines and tumors is enriched with stem-like cancer cells. Cancer Res. 2007;67:4827-4833.

9. Prince ME, Sivanandan R, Kaczorowski A, et al. Identification of a subpopulation of cells with cancer stem cell properties in head and neck squamous cell carcinoma. Proc Natl Acad Sci U S A. 2007;104: 973-978.

10. Harper LJ, Piper K, Common J, Fortune F, Mackenzie IC. Stem cell patterns in cell lines derived from head and neck squamous cell carcinoma. J Oral Pathol Med. 2007;36:594-603.

11. van der Windt GJ, Schouten M, Zeerleder S, Florquin S, van der Poll T. CD44 is protective during hyperoxia-induced lung injury. Am J Respir Cell Mol Biol. 2011;44:377-383.

12. Peterson LF, Wang Y, Lo MC, Yan M, Kanbe E, Zhang DE. The multifunctional cellular adhesion molecule CD44 is regulated by the $8 ; 21$ chromosomal translocation. Leukemia. 2007;21:2010-2019.

13. Hanagiri T, Shinohara S, Takenaka M, et al. Effects of hyaluronic acid and CD44 interaction on the proliferation and invasiveness of malignant pleural mesothelioma. Tumour Biol. Epub August 11, 2012.

14. Naor D, Nedvetzki S, Golan I, Melnik L, Faitelson Y. CD44 in cancer. Crit Rev Clin Lab Sci. 2002;39:527-579.

15. Fang XJ, Jiang H, Zhao XP, Jiang WM. The role of a new CD44st in increasing the invasion capability of the human breast cancer cell line MCF-7. BMC Cancer. 2011;11:290.

16. Marhaba R, Zöller M. CD44 in cancer progression: adhesion, migration and growth regulation. J Mol Histol. 2004;35:211-231.

17. Huet S, Groux H, Caillou B, Valentin H, Prieur AM, Bernard A. CD44 contributes to T cell activation. J Immunol. 1989;143:798-801.

18. Toyama-Sorimachi N, Miyasaka M. A sulfated proteoglycan as a novel ligand for CD44. J Dermatol. 1994;21:795-801.

19. Olsson E, Honeth G, Bendahl PO, et al. CD44 isoforms are heterogeneously expressed in breast cancer and correlate with tumor subtypes and cancer stem cell markers. BMC Cancer. 2011;11:418.

20. Brown RL, Reinke LM, Damerow MS, et al. CD44 splice isoform switching in human and mouse epithelium is essential for epithelialmesenchymal transition and breast cancer progression. J Clin Invest. 2011;121:1064-1074.

21. Peterson RM, Yu Q, Stamenkovic I, Toole BP. Perturbation of hyaluronan interactions by soluble CD44 inhibits growth of murine mammary carcinoma cells in ascites. Am J Pathol. 2000;156:2159-2167.

22. Lucas MG, Green AM, Telen MJ. Characterization of the serum In( $(\mathrm{Lu})-$ related antigen: identification of a serum protein related to erythrocyte p80. Blood. 1989;73:596-600.

23. Haynes BF, Hale LP, Patton KL, Martin ME, McCallum RM. Measurement of an adhesion molecule as in indicator of inflammatory disease activity. Up-regulation of the receptor for hyaluronate (CD44) in rheumatoid arthritis. Arthritis Rheum. 1991;34:1434-1443.
24. Guo YJ, Liu G, Wang X, et al. Potential use of soluble CD44 in serum as indicator of tumor burden and metastasis in patients with gastric or colon cancer. Cancer Res. 1994;54:422-426.

25. Van Hal NL, Van Dongen GA, Ten Brink CB, et al. Evaluation of soluble CD44v6 as a potential serum marker for head and neck squamous cell carcinoma. Clin Cancer Res. 1999;5:3534-3541.

26. Misra S, Ghatak S, Zoltan-Jones A, Toole BP. Regulation of multidrug resistance in cancer cells by hyaluronan. J Biol Chem. 2003; 278:25285-25288.

27. Osaki M, Kase S, Adachi K, Takeda A, Hashimoto K, Ito H. Inhibition of the PI3K-Akt signaling pathway enhances the sensitivity of Fasmediated apoptosis in human gastric carcinoma cell line, MKN-45. J Cancer Res Clin Oncol. 2004;130:8-14.

28. Cantley LC. The phosphoinositide 3-kinase pathway. Science. 2002; 296:1655-1657.

29. Graham VA, Marzo AL, Tough DF. A role for CD44 in T cell development and function during direct competition between CD44+ and CD44- cells. Eur J Immunol. 2007;37:925-934.

30. Ayroldi E, Cannarile L, Migliorati G, Bartoli A, Nicoletti I, Riccardi C. CD44 (Pgp-1) inhibits CD3 and dexamethasone-induced apoptosis. Blood. 1995;86:2672-2678.

31. Joshua B, Kaplan MJ, Doweck I, et al. Frequency of cells expressing CD44, a head and neck cancer stem cell marker: correlation with tumor aggressiveness. Head Neck. 2012;34:42-49.

32. Kunishi M, Kayada Y, Yoshiga K. Down-regulated expression of CD44 variant 6 in oral squamous cell carcinomas and its relationship to regional lymph node metastasis. Int J Oral Maxillofac Surg. 1997;26:280-283.

33. Negi LM, Talegaonkar S, Jaggi M, Ahmad FJ, Iqbal Z, Khar RK. Role of CD44 in tumour progression and strategies for targeting. J Drug Target. 2012;20:561-573.

34. Nagano O, Saya H. Mechanism and biological significance of CD44 cleavage. Cancer Sci. 2004;95:930-935.

35. Wang SJ, Wong G, de Heer AM, Xia W, Bourguignon LY. CD44 variant isoforms in head and neck squamous cell carcinoma progression. Laryngoscope. 2009;119:1518-1530.

36. Kokko LL, Hurme S, Maula SM, et al. Significance of site-specific prognosis of cancer stem cell marker CD44 in head and neck squamouscell carcinoma. Oral Oncol. 2011;47:510-516.

37. Rajarajan A, Stokes A, Bloor BK, et al. CD44 expression in oro-pharyngeal carcinoma tissues and cell lines. PLoS One. 2012;7:e28776.

38. Carinci F, Stabellini G, Calvitti M, et al. CD44 as prognostic factor in oral and oropharyngeal squamous cell carcinoma. J Craniofac Surg. 2002;13:85-89.

39. Lindquist D, Ahrlund-Richter A, Tarján M, Tot T, Dalianis T. Intense CD44 expression is a negative prognostic factor in tonsillar and base of tongue cancer. Anticancer Res. 2012;32: 153-161.

40. Fonseca I, Pereira T, Rosa-Santos J, Soares J. Expression of CD44 isoforms in squamous cell carcinoma of the border of the tongue: a correlation with histological grade, pattern of stromal invasion, and cell differentiation. J Surg Oncol. 2011;76: $115-120$.

41. Mostaan LV, Khorsandi MT, Sharifian SM, et al. Correlation between E-cadherin and CD44 adhesion molecules expression and cervical lymph node metastasis in oral tongue SCC: predictive significance or not. Pathol Res Pract. 2011;207:448-451.

42. Rodrigo JP, Domínguez F, Alvarez C, González MV, Herrero A, Suárez C. Clinicopathologic significance of expression of CD44s and CD44v6 isoforms in squamous cell carcinoma of the supraglottic larynx. Am J Clin Pathol. 2002;118:67-72.

43. Masuda M, Kuratomi Y, Shiratsuchi H, Nakashima T, Naonobu K, Komiyama S. Decreased CD44H expression in early-stage tongue carcinoma associates with late nodal metastases following interstitial brachytherapy. Head Neck. 2000;22:662-665.

44. Yüce I, Bayram A, Cağlı S, Canöz O, Bayram S, Güney E. The role of CD44 and matrix metalloproteinase-9 expression in predicting neck metastasis of supraglottic laryngeal carcinoma. Am J Otolaryngol. 2011;32:141-146. 
45. Uwa N, Kataoka TR, Torii I, et al. CD44 expression is related to poor prognosis of hypopharyngeal squamous cell carcinoma. Acta Otolaryngol. 2011;131:323-329.

46. de Jong MC, Pramana J, van der Wal JE, et al. CD44 expression predicts local recurrence after radiotherapy in larynx cancer. Clin Cancer Res. 2010;16:5329-5338

47. Sun B, Zhao S, Zhou C, Yan Q, Wang H. Detection of PD4, CD44, PCNA protein and its clinical significance in human laryngeal carcinoma. Lin Chung Er Bi Yan Hou Tou Jing Wai Ke Za Zhi. 2010;24: 817-819. Chinese.

48. Lu S, Tian J, Lv Z, et al. The probable role of tumor stem cells for lymph node metastasis in supraglottic carcinoma. Pathol Oncol Res. 2011;17:33-38.

49. Bourguignon LY, Wong G, Earle C, et al. Hyaluronan-CD44v3 interaction with Oct4-Sox2-Nanog promotes miR-302 expression leading to self-renewal, clonal formation, and cisplatin resistance in cancer stem cells from head and neck squamous cell carcinoma. J Biol Chem. 2012;287(39):32800-32824.

50. Allegra E, Puzzo L, Zuccalà V, et al. Nuclear BMI-1 expression in laryngeal carcinoma correlates with lymph node pathological status. World J Surg Oncol. 2012;10(1):206.

51. Allegra E, Caltabiano R, Amorosi A, Vasquez E, Garozzo A, Puzzo L. Expression of BMI1 and p16 in laryngeal squamous cell carcinoma. Head Neck. Epub June 22, 2012.

52. Allegra E, Trapasso S, Sacco A, et al. CD44 sol salivary levels detected by ELISA as a diagnostic test for laryngeal carcinomas. JCST. 2012;4(10):333-334.

53. Ioachim E, Assimakopoulos D, Goussia AC, Peschos D, Skevas A, Agnantis NJ. Glycoprotein CD44 expression in benign, premalignant and malignant epithelial lesions of the larynx: an immunohistochemical study including correlation with Rb, p53, Ki-67 and PCNA. Histol Histopathol. 1999;14:1113-1118.

54. Pereira LH, Adebisi IN, Perez A, et al. Salivary markers and risk factor data: a multivariate modeling approach for head and neck squamous cell carcinoma detection. Cancer Biomark. 2011;10:241-249.
55. Franzmann EJ, Reategui EP, Pereira LH, et al. Salivary protein and solCD44 levels as a potential screening tool for early detection of head and neck squamous cell carcinoma. Head Neck. 2012;34:687-695.

56. Franzmann EJ, Reategui EP, Pedroso F, et al. Soluble CD44 is a potential marker for the early detection of head and neck cancer. Cancer Epidemiol Biomarkers Prev. 2007;16:1348-1355.

57. Franzmann EJ, Reategui EP, Carraway KL, Hamilton KL, Weed DT, Goodwin WJ. Salivary soluble CD44: a potential molecular marker for head and neck cancer. Cancer Epidemiol Biomarkers Prev. 2005;14: 735-739.

58. Spafford MF, Koch WM, Reed AL, et al. Detection of head and neck squamous cell carcinoma among exfoliated oral mucosal cells by microsatellite analysis. Clin Cancer Res. 2001;7:607-612.

59. Carvalho AL, Jeronimo C, Kim MM, et al. Evaluation of promoter hypermethylation detection in body fluids as a screening/diagnosis tool for head and neck squamous cell carcinoma. Clin Cancer Res. 2008;14:97-107.

60. Califano J, Ahrendt SA, Meininger G, Westra WH, Koch WM, Sidransky D. Detection of telomerase activity in oral rinses from head and neck squamous cell carcinoma patients. Cancer Res. 1996;56:5720-5722.

61. Linkov F, Lisovich A, Yurkovetsky Z, et al. Early detection of head and neck cancer: development of a novel screening tool using multiplexed immunobead-based biomarker profiling. Cancer Epidemiol Biomarkers Prev. 2007;16:102-107.

62. Hoffman RM. Periodic PSA-based screening in men 55 to 69 years of age reduced prostate cancermortality. Ann Intern Med. 2012;157:JC1-JC4.

63. Allegra E, Garozzo A, Lombardo N, De Clemente M, Carey TE. Mutations and polymorphisms in mitochondrial DNA in head and neck cancer cell lines. Acta Otorhinolaryngol Ital. 2006;26(4):185-190.

64. Cruz MH, Sidén A, Calaf GM, Delwar ZM, Yakisich JS. The stemness phenotype model. ISRN Oncol. 2012;2012:392647.
Biologics: Targets \& Therapy

\section{Publish your work in this journal}

Biologics: Targets \& Therapy is an international, peer-reviewed journal focusing on the patho-physiological rationale for and clinical application of Biologic agents in the management of autoimmune diseases, cancers or other pathologies where a molecular target can be identified. This journal is indexed on PubMed Central, CAS, EMBase, Scopus

\section{Dovepress}

and the Elsevier Bibliographic databases. The manuscript management system is completely online and includes a very quick and fair peerreview system, which is all easy to use. Visit http://www.dovepress. com/testimonials.php to read real quotes from published authors. 